\title{
A COMMON EUROPEAN HOME and Turkey's Place in It
}

Prof. Dr. Türkkaya ATAÖV*

The notion of a common European home is gaining popularity, and intra-European relations are entering a new era. A "new thinking" is making inroads into the consciousness of Europeans. The future of that continent will probably be determined by its capacity to renew itself in the form of a multifaceted but integrated world.

The West has come a long way in reassessing the Soviet Union and the Eastern bloc of nations. Ex-President Ronald Reagan, who had described the Soviets as the "Kingdom of Evil", met General Secretary M.S. Gorbachov in Geneva (1985), Reykjavik (1986), Washington (1987) and in Moscow (1988) and signed the INF Treaty, which was the first real step in nuclear disarmament that has ever been made.

In an article that appeared in the Moscow-based Mejdunarodnaya Jizn (December 1988), Mr. Reagan rightly stressed that technology was transforming our lives, enabling individuals, thousands of miles apart from each other, to communicate as easily as if they were in the next room. Computers forecast weather for farmers, translate English into Russian or enable the blind to read. The American public is also willing to experiment with winding down the cold war. Although this "new thinking" in the United States is different from that of Mr. Gorbachov, who wants changes to take place swiftly, the American public is shifting too. A number of projects, such as "Americans Talk Security" (a series of twelve bipartisan surveys) and another jointly administered by "The Public Agenda Foundation" and Brown University, offer overwhelming evidence that the average American is changing his outlook on U.S.U.S.S.R. relations.

Expanding this new vista, Mr. Gorbachov stated that although Marxism believed in the elimination of capitalism through war, the dangers of

" Talk prepared for the "International Symposium: Visions of Future Europe", Cracow, Poland, April 19-21, 1989. 
a nuclear conflict lead the Soviet Union to decide that this cause-andeffect relationship between war and revolution ought to disappear. Peaceful coexistence was no longer a form of ideological struggle.

The prevention of self-destruction is increasingly becoming the foremost task of governments and peoples alike. On the military plane, all seem to be aware that an armed conflict, waged with nuclear weapons, can only bring mutual annihilation. Militarism perhaps still dominates, but it also bears within itself the seed of its own destruction. The two cintending sides are creating the bases of a renovated approach to military balance. The powers grasp the value of emphasizing the need for a ccmmon life. An attempt to introduce new weapons or new systems may harm this tendency to subordinate all matters to the basic rational of eliminating war as a means to solve disputes. Ideological differences are pushed into the background, and states, especially those in Europe, are searching ways to establish mutually useful relations.

A common European home implies the prerequisite of a realistic study of the existing circumstances. The two military blocs facing each other in Europe will probably continue to exist for some time to come. It is difficult for the European countries to scrap at once the present structure of relations for the purpose of building a new association. However, this does not prevent the Europeans to seek new frameworks of cooperation, which may be better guarantees of security.

Furthermore, security is an essential but an insufficient foundation for building a common European home. The accent should shift from a ne Eative orientation of avoiding mulual destruction to a positive adaptation of non-military goals. On the economic level, the Eastern European countries are aware that the European community has experienced a dynamic economic growth. A number of socialist countries have established relations with the West. The former argument that there are two separate economic markets, namely, a socialist one and a capitalist one, is repudiated. Not only the Soviet Union and some Eastern European countries favour building market mechanisms into socialism, but also the Eastern camp will benefit from this cooperation in solving its difficulties. Western Europe, as well, views the East as a large market for export and import opportunities. The efforts of Western Europe to utilize capital investment and engage in joint ventures are assisted by the elimination of some obsolete barriers in the Eastern community. Both sides are on the verge of a new association on the economic plane.

In spite of the lack of success recorded by a number of several attempts at "integration" elsewhere, the international community still 
continues to encourage economic cooperative experiments. More recent attempts try to avoid the pitpalls of overambition and apply the lessons learned from previous disappointing experiences.

On the political level, there is a new image of international relations. Ideological tensions having been reduced, relaxation on the continent is gaining ground. Europe has experienced one of the longest periods of peace in its entire history. The forces in favour of relaxation are translating the values of the new context into specific political actions.

While material production symbolizes man's economic activity, culiure is the embodiment of spiritual communication. They are two aspects of the same phenomenon, that is, man's endeavour to transform the world. Cultural production is an integrated system in which science and education interact. On the basis of accumulated knowledge and experience in both halves of the European Continent, the people of the East and the West may enrich their intellectual and aesthetic values. Such a goal necessitates the improvement of information exchange.

The idea of a common European home is impossible without recognization of all its component parts, without a search for interests common to all inhabitants of the continent.

Changed relations at the summit of the two super powers, a serious destabilization in either bloc or a local armed conflict threatening to escalate may challenge the present balance. Although there is the possibility of discord or hostility, they may be resolved with less effort in an atmosphere of diminished ideological strains.

The role of sub-regional structures, among them, the Balkans, Northern Europe and the Mediterranean, is enchancing as well, and some of these groupings may serve as natural bridges connecting Europe with the neighbouring continents. The European processes will trigger responses in Asia, Africa and the rest of the globe.

\section{*t:}

Where does Turkey stand in this quest for a continental personality and a meaningful universal experiment?

Geography and history have made the Turks a Central Asian, a Near and Middle Eastern, a Mediterranean, a Balkan, a European and a Black Sea people. At different times, they possessed all or most of the attributes referred to above. Even after the disintegration of the Ottoman Empire, the Balkanic element is still a component of Turkish identity. Turkey, 
which has some territory in Europe, is also a Middle Eastern country with close relations with the Moslem world. It also has long shores on the Black Sea and the Mediterranean, linking that country with the Eastern and Southern portions of the European Continent. Turkey is a member of the Council of Europe, OECD and NATO and applied for full membership in the European Community. Turkey emphasizes one or the other aspect of its identity slanting to one side when there is a disappointment from the other. However, there is no contradiction in this behaviour because Turkey possesses all of these attributes.

The Turks are the descendants of nomads who roamed in what is now known as Central Asia. Their rise to rule much of Europe and Asia is remarkable history. Beginning in the Second Century before Christ, changing climatic and political conditions in the Altaic homeland sent successive waves in all directions, principally towards the West. Those who were Westward bound called themselves "Oghuz" while those" who came into contact with them knew them as "Turcomans" or "Turks".

The different waves of migration were exemplified by the Huns, the Avars, the Magyars, the Bolgars and the Pecheneks. The earliest known Turkish political entity was the Göktürk Empire (552-744), stretching from the Black Sea almost to the Pacific Ocean. The Seljuk Turks, who put parts of Iran, Iraq and Syria under their control, entered Anatolia (Asia Minor), blending Turkish-Islamic and Christian civilizations.

The Ottomans advanced rapidly into the heart of Europe, developing a system of rule by which the native Christian rulers retained their positions for acknowledging Turkish sovereignty. The Ottomans pursued the Islamic policy of tolerance towards the "people of the book", that is, the Christians and the Jews, who escaping from the Inquisition, found a haven in Ottoman lands. The Turkish administration gave the patriarchs and the rabbis civil as well as religious authority over their own people. Thus was created the millet system of autonomous self-government extended to the Orthodox Christians, the Armenians, the Jews and later to the other non-Moslems. For the first 218 years of its existence (1299-1517), the Ottoman people were mainly composed of the Christian subjects, until Selim the First was urged to turn to the Safavid danger coming from Iran and to the Mamelukes in Syria and Egypt.

Some of the traditional Ottoman ways had to be abandoned when the complex structure of the society began to decay, leading to loss of territory and increasing domination by the European powers. The Ottoman state was, nevertheless, a part of the European Concert of nations and of European diplomacy. 
Turkey's westernization efforts date back to the end of the Eighteenth Century, when that country bordered Austria. When the Ottoman Parliament was opered in 1877 as part of the modernization drive, the European provinces and the non-Moslems were considerably over-represented. And when the Ottoman Empire entered into a long process of disintegration, the Russian Tsar referred to it as "the sick man of Europe". For seven centuries Turkish history has been an integral part of European history.

The process of westernization continued to gain momentum, culminating in the proclamation of the Republic (1923), at a time when Turkey was surrounded by royal régimes - save the Soviet Union. Kemalist reforms constitute the basis of the pluralist political life today. Turkey is also a secular state among the Moslem countries of the Middle East. Moreover, there are, not only sizable Turkish minorities in a number of Balkan countries (such as Moslem Turks in Bulgaria and Greece and Christian Gagauz in Romania), but also some millions of Turkish migrant workers in Western Europe.

With a population of over fifty millions, qualified working force, rich natural resources, high agricultural potential and large domestic market, Turkey can contribute favourably to any group of countries at regional or continental level.

If the European states steadily improve the relations between themselves, this trend will in due course spread to other countries, giving neodétente a universal meaning. This drift is a search for a synthesis for the whole world. The example of Turkey provides a meaningful test for a much wider experiment. Turkey's acceptance as a European community as well can only serve to pave the way for the mutual acceptance of all the other societies which need to be integrated into a comprehensive whole. 